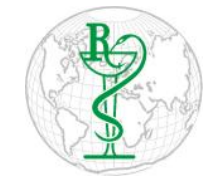

INDO GLOBAL JOURNAL OF

PHARMACEUTICAL SCIENCES

ISSN 2249- 1023

\title{
Molecular Docking Studies of Deva Chooranam against the Target Protein 6LU7 of Novel Corona Virus 2019
}

\author{
Thangadurai K ${ }^{*}$, Rengasundari ${ }^{2}$, Saravana Siva $\mathrm{P}^{3}$, Vithyavani N ${ }^{4}$, Sivasankari K ${ }^{5}$, Ramya $\mathrm{R}^{6}$, \\ Jeeva Gladys R ${ }^{7}$, Kannan K.P. ${ }^{8}$ \\ ${ }^{1}$ Department of Maruthuvam, JSA Medical college for Siddha and research centre, Ulundurpet, Villupuram, Tamilnadu, India \\ ${ }^{2}$ Maria Siddha Medical College and Hospital, Thottavaram, Kalkulam Taluk, Kanyakumari District, Tamil Nadu, India. \\ ${ }^{3}$ Agara Super speciality Siddha clinic, Thirumullaivoiyil, Chennai, Tamil Nadu-600062, Treasurer - Lions Club of Chennai AAYUSH (DIST.324-A1). \\ ${ }^{4}$ SiddhaChikitsalaya, Groundfloor, Rap Towers, SaraswathyNagar, Nellore, Andhra Pradesh-524003, India \\ ${ }^{5}$ Freelancer, San Jose, California, United states of America- 95123 \\ ${ }^{6}$ Department of Sirappu Maruthuvam, Velumailu siddha Medical College,Sriperumbudur, Tamil Nadu, India-602105 \\ ${ }^{7}$ Department of Research methodology and Medical statistics, Velumailu siddha Medical College,Sriperumbudur, Tamil Nadu, India-602105 \\ ${ }^{8}$ JSA Siddha Medical College and Research centre, Pali, Ulundurpet, TamilNadu-606104
}

Address for Correspondence: Thangadurai, K., drkthangadurai@gmail.com

\section{Received: \\ 15.05.2020 \\ Accepted: \\ 25.05.2020 \\ Published: \\ 21.12.2020}

Keywords

Novel

coronavirus,

Deva

Chooranam,

Main Protease,

Luteolin,

Phytocompound.
ABSTRACT: Plants and bioactive compounds have played an important role in the development of several clinically useful therapeutic agents since time immemorial. In the recent years, more emphasis has been placed on identifying plant-derived compounds that can be used as an effective treatment for lifethreatening diseases. COVID-19, a new strain of coronavirus (CoV), was identified in Wuhan, China, in 2019. No specific therapies are available and investigations regarding COVID-19 treatment are lacking. Bioactive compounds found in Siddha herbal formulation Deva Chooranam which was previously confirmed through molecular docking to have antiviral effects against HIV -RT. The present study aimed to assess Deva Chooranam as potential COVID-19 Mpro inhibitor. Molecular docking was performed using Autodock 4.2, with the Lamarckian Genetic Algorithm and results were visualized using pymol. The physiochemical and ADMET(Adsorption, distribution, metabolism and excretion) properties were also analysed.COVID-19 Mpro was docked with several compounds, Eugenol A-Pinene, Atlantone, Myrcene , Luteolin, Apigenin, Kaempferol and docking was analysed using Pymol. The results showed that out of the 7 compounds screened Luteolin appeared to have the best potential binding against the COVID-19 Mpro 6LU7. However, further research is necessary to investigate their potential medicinal use. () 2020 iGlobal Research and Publishing Foundation. All rights reserved.

Cite this article as: Thangadurai, K.; Rengasundari; Saravana Siva, P.; Vithyavani, N.; Sivasankari, K.; Ramya, R.; Jeeva Gladys, R.; Kannan, K.P. Molecular docking studies of Deva Chooranam against the target protein 6LU7 of novel corona virus 2019. Indo Global J. Pharm. Sci., 2020; 10(2): 19-25. DOI: http://doi.org/10.35652/IGJPS.2020.10204.

\section{INTRODUCTION}

The new strain of Coronaviruses (CoVs) was recognized at the end of 2019, initially named 2019-nCoV, and emerged during an outbreak in Wuhan, China.[1] They are large, enveloped, positive-strand RNA viruses that are named for the crown-like spikes on their surface. Rarely, animal coronaviruses can infect people and then spread between people and are an etiologic agent of severe respiratory tract infections in both humans and animals, which can cause disorder not only in the respiratory tract, digestive tract and systemic infections.[2,3] Officially, WHO named this $\mathrm{CoV}$ COVID-19 (Coronavirus disease 2019), on February 11, 2020, based on consultations and collaborations with the World 


\section{Indo Global Journal of Pharmaceutical Sciences, 2020; 10(2): 19-25}

Organization for Animal Health and the Food and Agriculture Organization of the United Nations.[4] While there are, no specific therapies for COVID-19 and investigations regarding the treatment of COVID-19 are lacking, preventive and supportive therapies to prevent further complications and organ damage seems to be essential at this crucial stage. Some earlier preliminary studies have investigated protease inhibitor which is commonly used to treat human immunodeficiency virus (HIV)/acquired immunodeficiency syndrome patients, as a potential target for the inhibition of $\mathrm{CoV}$ replication for the treatment of COVID-19-infected patients.[5] The COVID-19 main protease (Mpro), is a potential drug target. In the present study, we investigated Eugenol A-Pinene, Atlantone, Myrcene, Luteolin, Apigenin, Kaempferol as lead compounds from the ingredients Cedrus deodara (Devadaru), Alpinia galanga (Arathai), Cinnamomum tamala (Lavanga pathiri) of Deva chooranam as potential inhibitor candidates for COVID19 Mpro . The findings of the present study will provide other researchers with opportunities to identify a supportive therapy to combat COVID-19.

\section{Literature review on Ingredients of Deva Chooranam (DC)}

Deva Chooranam (DC) is a Siddha herbal formulation consisting of three medicinal herbs, Cedrus deodara (Devadaru), Alpinia galanga (Arathai) and Cinnamomum tamala (Lavanga pathiri). These herbs have been mentioned in Agathiyar gunavagadam a classical Siddha literature is and they are indicated for fever, cough, wheeze, respiratory illness, diarrhea, dysentery, dehydration, respiratory ailments that can be found in the clinical conditions of COVID-19. [6] Previous work on Aplinia galangal has confirmed that Virtual screening of natural product compounds into the solvent accessible S3S4 pocket of PLPro showed that eight compounds found in rhizomes of Alpinia officinarum were identified as potential inhibitors of SARS-CoV-2 PLpro. Hence the previous study on structure based molecular docking show these natural product inhibitors are promising drug candidates against SARS-CoV-2.[7] Another study by Mishra et al., in their phytochemical analysis confirmed the presence of various secondary metabolites in Cinnamomum tamala such as alkaloids, flavonoids, terpenoids and tannins.[8] Alkaloids show antihelminthic, antidiarrhoeal and antimicrobial activities.[9] and act as inhibitor, stimulator and growth terminator.[10] On the other hand, flavonoids exhibit antiviral, antioxidant and anti-inflammatory activities .Tannins and terpenoids act as primary antioxidants or free radical scavengers and work synergistically with each other to create a broad spectrum of antioxidative actions that generates an operative defense system against free radical attack.[11] The study by Chaurasia JK et al., clearly portrays that non-polar hexane fraction of leaves of Cinnamomum tamala possesses immunosuppressive property, which is mediated through modulation of innate immunity.[12] Studies on Cedrus deodara showed that Cedrus genus have cytotoxic, spasmolytic immunomodulatory, antiallergic, antiinflammatory and analgesic activities. The essential oil isolated from Cedrus leaves may bear potential for drug development due to its high concentrations of germacrene D and $\beta$-caryophyllene and also show bioactivity against bacteria and viruses. [13]

\section{MATERIALS AND METHODS}

\section{Target Selection and Preparation}

6LU7 is the structure of human coronavirus NL63 main protease in complex with the alpha-ketoamide (S)-N-((S)-4(benzylamino)-3,4-dioxo-1-((S)-2-oxopyrrolidin-3-yl)butan-2yl)-2-cinnamamido-4-methylpentanamide (cinnamoyl-leucineGlnLactam-CO-CO-NH-benzyl). It pays a key role in incorporating the genomic RNA into progeny viral particles and was considered a potential target. The selected structure was optimized by adding the polar hydrogen atom. The macromolecule was converted into PDBQT format before performing docking.

Table 1. List of phytocompounds

\begin{tabular}{|c|c|c|}
\hline $\begin{array}{c}\text { S.N } \\
\text { o }\end{array}$ & $\begin{array}{c}\text { Medicinal } \\
\text { Plants }\end{array}$ & $\begin{array}{c}\text { Phytocompounds/Baoactive } \\
\text { compounds }\end{array}$ \\
\hline 1 & $\begin{array}{c}\text { Cinnamomum } \\
\text { tamala }\end{array}$ & $\begin{array}{c}\text { Eugenol } \\
\text { A-Pinene }\end{array}$ \\
\hline 2 & $\begin{array}{c}\text { Cedrus } \\
\text { deodara }\end{array}$ & $\begin{array}{c}\text { Atlantone } \\
\text { Myrcene }\end{array}$ \\
\hline 3 & Alpinia & Luteolin \\
& officinarum & Apigenin \\
& & Kaempferol \\
\hline 4 & AntiHIV drug & Nelfinavir \\
& & \\
\hline
\end{tabular}

${ }^{*}$ The italic denotes the botanical name of the medicinal plants

\section{Ligand selection and preparation}

The three major plants namely Cinnamomum tamala, Cedrus deodara, Alpinia officinarum were considered for the study as they are the active herbs of Deva Chooranam (Table 1). The main phytocompounds of these medicinal plants were retrieved from Pubchem and all the phytocompounds were optimized before docking an anti-retroviral drug Nelfinavir was also used. The chemical structure of the ligand molecules are given in the (Fig.1).

\section{Molecular docking}

Docking calculations were carried out using Auto Dock 4.3. Gasteiger partial charges were added to the ligand atoms. 
Indo Global Journal of Pharmaceutical Sciences, 2020; 10(2): 19-25

Docking calculations were performed for phytocompounds and standard drug Nelfinavir against the target protein. Essential hydrogen atoms, Kollman united atom type charges, and solvation parameters were added and the target protein and ligands were prepared in AutoDock tools. [14] The X Y and $\mathrm{Z}$ coordinates were set at $-25,12$ and 59 respectively. The grid was placed at 25 for $\mathrm{X}, \mathrm{Y}$ and $\mathrm{Z}$ and an Autogrid program was generated. Docking simulations were performed using the Lamarckian genetic algorithm (LGA) and the Solis \& Wets local search method. [15] A total of 10 different docking pores were obtained for each docked molecules and the best pore was evaluated.

Table 2. Physiochemical properties of phytocompounds

\begin{tabular}{|c|c|c|c|c|c|c|}
\hline Ligands & Canonical SMILES & Formula & $\begin{array}{c}\text { Molecular } \\
\text { Weight (kDa) }\end{array}$ & $\begin{array}{l}\text { Lipi } \\
\text { nski } \\
\text { rule }\end{array}$ & $\begin{array}{c}\text { H-bond } \\
\text { acceptors }\end{array}$ & $\begin{array}{l}\text { H-bond } \\
\text { donors }\end{array}$ \\
\hline Eugenol & $\mathrm{C}=\mathrm{CCc} 1 \mathrm{ccc}(\mathrm{c}(\mathrm{c} 1) \mathrm{OC}) \mathrm{O}$ & $\begin{array}{c}\mathrm{C} 10 \mathrm{H} 12 \mathrm{O} \\
2\end{array}$ & 164.2 & 0 & 2 & 1 \\
\hline $\begin{array}{l}\text { Alpha- } \\
\text { Pinene }\end{array}$ & $\mathrm{CC} 1=\mathrm{CCC} 2 \mathrm{CC} 1 \mathrm{C} 2(\mathrm{C}) \mathrm{C}$ & $\mathrm{C} 10 \mathrm{H} 16$ & 136.23 & 0 & 0 & 0 \\
\hline $\begin{array}{l}\text { Alpha- } \\
\text { Atlantone }\end{array}$ & $\mathrm{CC}(=\mathrm{CC}(=\mathrm{O}) \mathrm{C}=\mathrm{C}(\mathrm{C} 1 \mathrm{CCC}(=\mathrm{CC} 1) \mathrm{C}) \mathrm{C}) \mathrm{C}$ & $\mathrm{C} 15 \mathrm{H} 22 \mathrm{O}$ & 218.33 & 0 & 1 & 0 \\
\hline Myrcene & $\mathrm{C}=\mathrm{CC}(=\mathrm{C}) \mathrm{CCC}=\mathrm{C}(\mathrm{C}) \mathrm{C}$ & $\mathrm{C} 10 \mathrm{H} 16$ & 136.23 & 0 & 0 & 0 \\
\hline Luteolin & $\mathrm{Oc} 1 \mathrm{cc}(\mathrm{O}) \mathrm{c} 2 \mathrm{c}(\mathrm{c} 1) \mathrm{oc}(\mathrm{cc} 2=\mathrm{O}) \mathrm{c} 1 \mathrm{ccc}(\mathrm{c}(\mathrm{c} 1) \mathrm{O}) \mathrm{O}$ & $\begin{array}{c}\mathrm{C} 15 \mathrm{H} 10 \mathrm{O} \\
6\end{array}$ & 286.24 & 0 & 6 & 4 \\
\hline Apigenin & $\mathrm{Oc} 1 \mathrm{ccc}(\mathrm{cc} 1) \mathrm{c} 1 \mathrm{cc}(=\mathrm{O}) \mathrm{c} 2 \mathrm{c}(\mathrm{o} 1) \operatorname{cc}(\mathrm{cc} 2 \mathrm{O}) \mathrm{O}$ & $\begin{array}{c}\mathrm{C} 15 \mathrm{H} 10 \mathrm{O} \\
5 \\
\end{array}$ & 270.24 & 0 & 5 & 3 \\
\hline $\begin{array}{c}\text { Kaempfero } \\
1 \\
\end{array}$ & Oc1 $\operatorname{ccc}(\operatorname{cc} 1) \mathrm{c} 1 \mathrm{oc} 2 \mathrm{cc}(\mathrm{O}) \mathrm{cc}(\mathrm{c} 2 \mathrm{c}(=\mathrm{O}) \mathrm{c} 1 \mathrm{O}) \mathrm{O}$ & $\begin{array}{c}\mathrm{C} 15 \mathrm{H} 10 \mathrm{O} \\
6 \\
\end{array}$ & 286.24 & 0 & 6 & 4 \\
\hline Nelfinavir & $\begin{array}{c}\mathrm{OC}(\mathrm{C}(\mathrm{NC}(=\mathrm{O}) \mathrm{c} 1 \operatorname{ccc}(\mathrm{c} 1 \mathrm{C}) \mathrm{O}) \mathrm{CSc} 1 \mathrm{ccccc} 1) \mathrm{CN} 1 \\
\mathrm{CC} 2 \mathrm{CCCCC} 2 \mathrm{CC} 1 \mathrm{C} \\
(=\mathrm{O}) \mathrm{NC}(\mathrm{C})(\mathrm{C}) \mathrm{C}\end{array}$ & $\begin{array}{c}\mathrm{C} 32 \mathrm{H} 45 \mathrm{~N} \\
3 \mathrm{O} 4 \mathrm{~S}\end{array}$ & 567.78 & 1 & 5 & 4 \\
\hline
\end{tabular}

${ }^{\mathrm{a}} \mathrm{H}$ denotes Hydrogen.

Table 3. Hydrogen bond-interaction profile of ligands against target protein 6LU7

\begin{tabular}{|c|c|c|l|l|l|l|l|}
\hline & $\begin{array}{c}\text { Binding } \\
\text { energy } \\
\text { Phytocompounds }\end{array}$ & $\begin{array}{c}\text { Number of } \\
\text { Interactions }\end{array}$ & \multicolumn{5}{|l|}{ Amino Acid - HB interactions } \\
\hline Luteolin & -7.1 & 5 & LYS102 & SER158 & ASP153 & THR111 & GLN110 \\
\hline Apigenin & -6.7 & 3 & THR292 & THR111 & GLN110 & - & - \\
\hline Kempferol & -6.4 & 3 & PHE294 & ASP295 & GLN110 & - & - \\
\hline Atlantone & -6.2 & 1 & SER158 & - & - & - & - \\
\hline Eugenol & -5.5 & 3 & GLN110 & THR111 & PHE112 & - & - \\
\hline Nelfinavir & -6.2 & 2 & GLY138 & LYS137 & - & - & - \\
\hline
\end{tabular}

${ }^{\mathrm{a}} \mathrm{HB}$ - denotes Hydrogen Bond , ${ }^{\mathrm{b}}$ LYS-Lysine, ${ }^{\mathrm{c}} \mathrm{SER}-\mathrm{Amino}$ acid, ${ }^{\mathrm{d}}$ ASP- Aspartate, ${ }^{\mathrm{e}}$ THR-Threonine, ${ }^{\text {f PHE- Phenylalanine }}{ }^{\mathrm{g}} \mathrm{GLN}-$ Glutamic acid

Table 4. ADMET analysis of the best ranked Ligands

\begin{tabular}{|l|l|l|r|r|}
\hline Ligands & GI absorption & BBB penetration & Bioavailability Score & Synthetic Accessibility \\
\hline Eugenol & High & Yes & 0.55 & 1.58 \\
\hline Luteolin & High & No & 0.55 & 3.02 \\
\hline Apigenin & High & No & 0.55 & 2.96 \\
\hline Kaempferol & High & No & 0.55 & 3.14 \\
\hline
\end{tabular}

${ }^{\mathrm{a}}$ GI - Gastro Intestinal, ${ }^{\mathrm{b}} \mathrm{BBB}-\mathrm{Blood}$ Brain Barrier 
Indo Global Journal of Pharmaceutical Sciences, 2020; 10(2): 19-25

\section{Physiochemical and ADMET analysis}

The physiochemical properties of all the phytocompounds used in the study was evaluated and out of which the finally screened hits were evaluated for their ADMET properties. All the properties were predicted using the software Swiss ADMET.

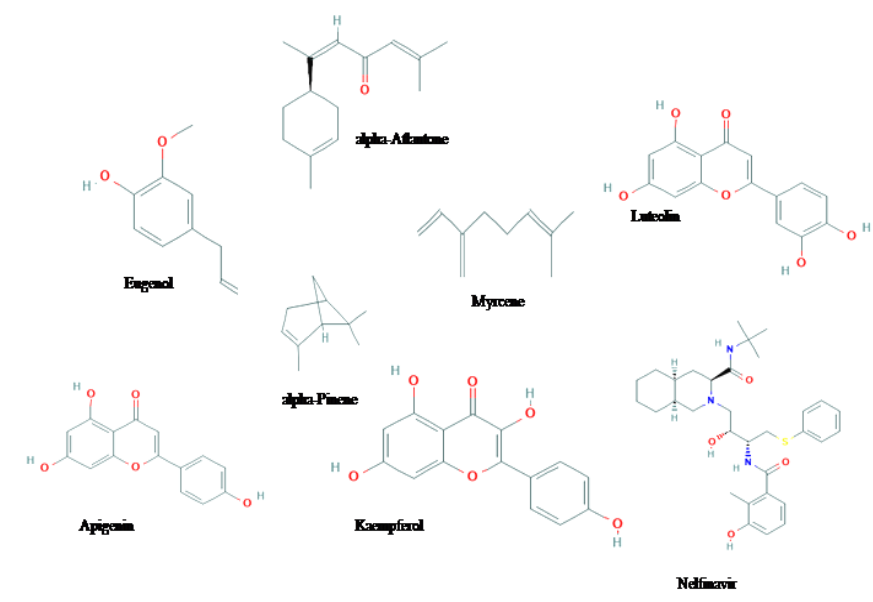

Figure 1. Chemical Structure of Ligand Molecules.

\section{RESULTS AND DISCUSSION}

The important phytocompounds from the three important medicinal plants namely Cinnamomum tamala, Cedrus deodara and Alpinia officinarum were taken for the study. The target protein 6LU7 was targeted for the phytocompounds Eugenol, $\alpha$-Pinene, Atlantone, Myrcene, Luteolin, Apigenin and Kaempferol and anti retroviral drug Nelfinavir. The physiochemical properties of the phytocompounds were determined and it was found that except the FDA approved drug Nelfinavir rest fit well into the Lipinski rule of five the details is given in Table 2 .

The ligand molecules were subjected to docking analysis using Autodock 4.1 version and the binding site was identified and the active site is given in the Fig $\mathbf{2}$. The result of the interaction profile of phytocompounds above a binding energy value of $-5.5 \mathrm{Kcal} / \mathrm{mol}$ were tabulated in Table 3. The results were further scrutinized based on the binding energy and amino acids contributing in the formation of hydrogen bonds. The best ligands that potentially inhibit 6LU7, and their docked confirmation is given in (Fig 3 to Fig 6). The docking study revealed that the ligand Luteolin exhibited the highest binding energy of $-7.1 \mathrm{Kcal} / \mathrm{mol}$ followed by Apigenin with a binding energy of $-6.7 \mathrm{kcal} / \mathrm{mol}$. The phytocompounds Kempferol and Eugenol exhibited a binding energy of $6.4 \mathrm{kcal} / \mathrm{mol}$ and $-5.5 \mathrm{kcal} / \mathrm{mol}$ respectively.
The ADMET analyses of the best ranked phytocompounds were predicted and it was observed that all the compounds have good gastrointestinal adsorption with a bioavailability of 0.55 , futher the phytocompounds did not cross the blood brain barrier as detailed in Table 4. As it is well known fact that the new Coronavirus (CoV) identified as COVID-19 is responsible for the viral pneumonia outbreak that commenced in Wuhan during 2020[16]. The major theme of the study evolved as there is no approved antiviral to effectively treat this infection. The study was famed in such a way that we can come out few phytocompounds that could serve the purpose. A computer assessed drug screening was performed for the phytocompounds obtained for the few herbal plants which is widely used in the treatment of different infections. The target protein used in this study was the main protease (Mpro). Mpro that played a key role in the viral replication5,6 and so it was believed that targeting this protein will provide effective outcome.

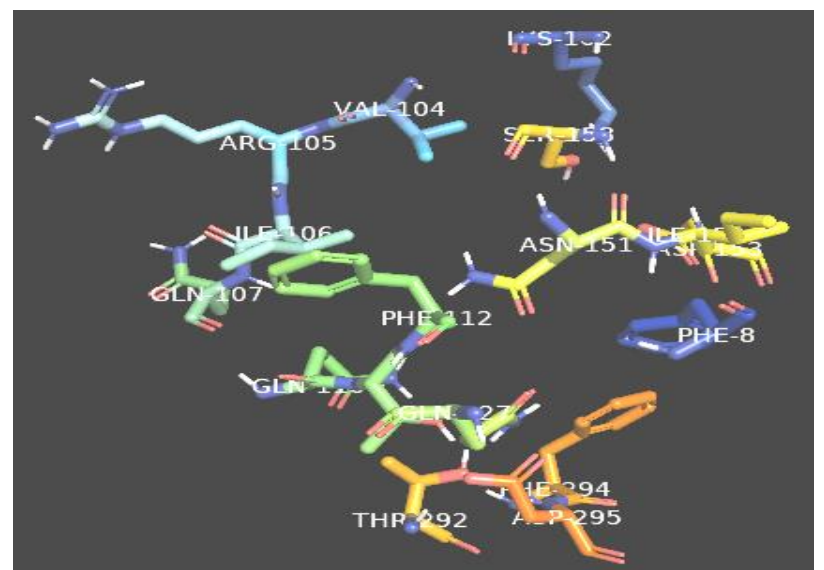

Figure 2. Active site of Main protease of COVID 19 (6LU7)

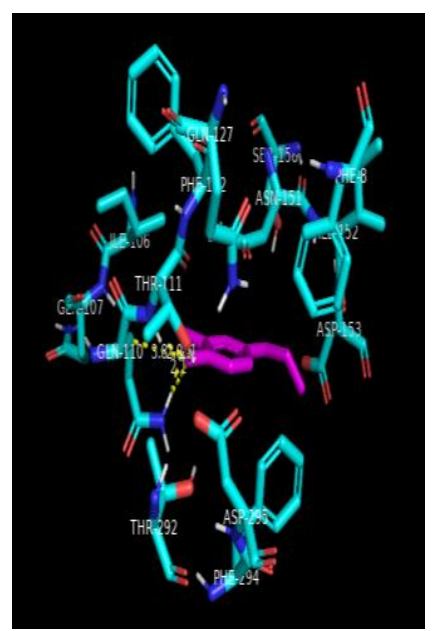

Figure 3. Docked confirmation of luteolin with the active site of 6LU7 and key HB interactions 
Indo Global Journal of Pharmaceutical Sciences, 2020; 10(2): 19-25

Now research on COVID 19 is a very important since the outbreak is a pandemic and it has already killed many and it is a common threat around the globe. Many countries are following different mode of drug regime to treat and there is an urgent need for new drugs, hence this led to this research work to provide new insight in the development of antivirals and to fight against COVID 19. Since the compounds chosen for the study are phytocompounds this would be of least side effects. Few researchers have worked on various sets of phytocompounds like flavanoids targeting the spike protein.[7] For example, the constituents of black tea against the main protease and reported that theaflavin digallate as the potential inhibitor of main protease.[17]

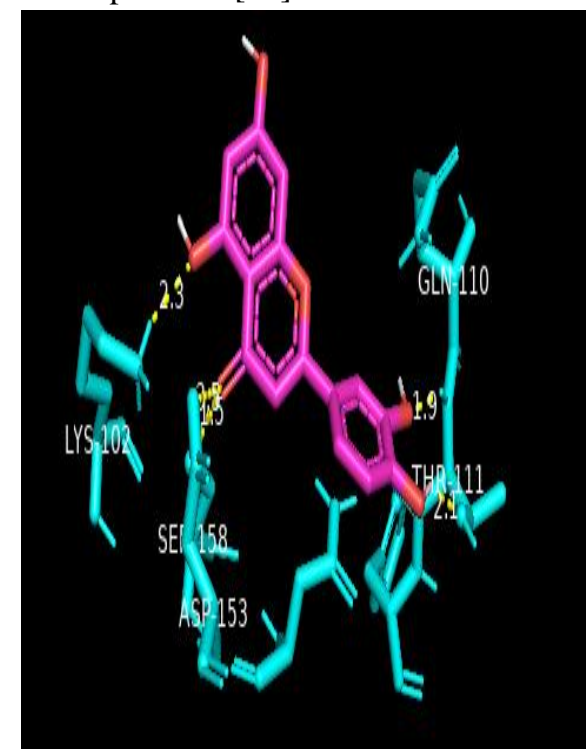

Figure 4. Docked confirmation of Apigenin with the active site of 6LU7 and key HB interactions

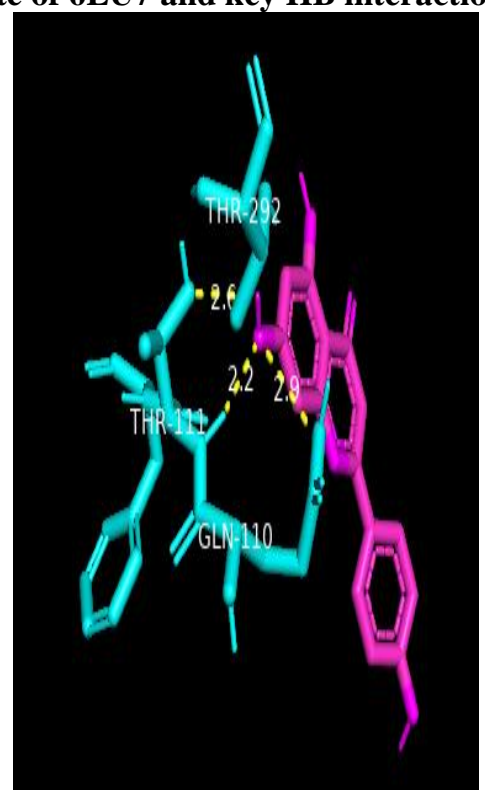

Figure 5. Docked confirmation of Kempferol with the active site of 6LU7 and key HB interactions
Flavonoids are believed to the common group of phytocompounds having potential activity in the prevention and treatment of several diseases that includes antioxidant, anti-inflammatory, antimicrobial and anticancer activities.[18] In general the flavonoids are reported to have effective antiviral activity against various viruses.[19-21] In our study we have taken the major phytocompounds from the three plants namely Cinnamomum tamala, Cedrus deodara and Alpinia officinarum which are the major constituents of the Siddha drug the Deva Chooranam a clinically important formulation for the treatment of HIV. We have performed a previous study to evaluate the antiviral activity of major phytocompounds from the three medicinal against HIV Protein using an in silco approach.[22]

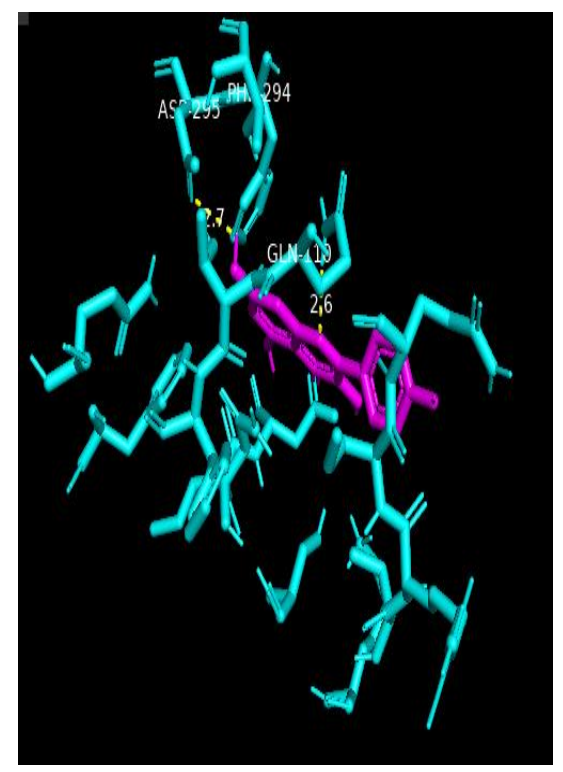

Figure 6. Docked confirmation of Eugenol with the active site of 6LU7 and key HB interactions

In our present study, the phytocompounds were docked to the active site of 6LU7, the main protease of Coronavirus and it was found that the compound Luteolin showed the highest binding energy of -7.1 forming hydrogen bonding with LYS102, SER158, ASP153, THR111 and GLN110. Luteolin is one of the most common flavonoid present in edible plants and traditional medicinal plants. S Adem et al 2020 had reported that hesperidin, rutin, diosmin had the highest binding energy out of the 80 flavoniod docked against the same target 6LU7.[23] From this study it is positive to note that phytocompounds could serve as effective, safe and cost effective with no side effects. Such studies could come up with new intervention which can serve the scientific community for future studies. 


\section{Indo Global Journal of Pharmaceutical Sciences, 2020; 10(2): 19-25}

\section{CONCLUSION}

The novel coronavirus is an emerging problem with no approved drug or treatment protocol is available to treat this pandemic infection. Many researchers are working on the various aspects of novel coronavirus and in this study we have tried to shed light into the use of phytocompounds as an effective candidate in the treatment of the infection. Outcome of this study has come out with a flavonoid luteolin which has already reported to have many biological activates. Based on the docking study performed it was found that luteolin found to posses highest binding affinity against Mpro that plays a key role in the viral replication of Novel Corona virus 2019. Therefore it can be recommended for further investigation to prove its use in the antiviral therapy.

\section{ACKNOWLEDGEMENT}

The author wishes to acknowledge Dr.Yuvaraj M.S, Anesthetist, Bharathirajaa Hospital and research centre Pvt Ltd, Chennai, India for his kind contribution and support towards publishing this study.

\section{CONFLICTS OF INTEREST}

Authors declare that there are no conflicts of Interest among them.

\section{FUNDING INFORMATION}

Nil

\section{DATA AVAILABILITY}

Not declared.

\section{REFERENCES}

1. Lee PR, Hsueh PI, Emerging threats from zoonotic coronaviruses-from SARS and MERS to 2019- nCoV. J. Microbiol. Immunol. Infect. 2020, 1-3.

2. Malik YS, Sircar S, Bhat S, Sharun K, Dhama K, Dadar M, Tiwari R, Chaicumpa W. Emerging novel Coronavirus (2019nCoV) - Current scenario, evolutionary perspective based on genome analysis and recent developments. Veterinary quarterly. 2020, 40: 1-12.

3.CDC Health Alert Network Advisory Update and Interim Guidance on Outbreak of 2019 Novel Coronavirus (2019nCoV) in Wuhan, China. URL: https://www.cdc.gov/csels/dls/locs/2020/outbreak-of-2019novel-coronavirus-2019-ncov-in-wuhan-china.html 4.World Health Organization (WHO), "Novel Coronavirus ( 2019-nCoV )," WHO Bull., 2020;1-7, URL: https://www.who.int/docs/default-

source/coronaviruse/situation reports/20200121-sitrep-1-2019ncov.pdf
5. Xu Z, Peng C, Y Shi Z, Zhu K, Mu Wang X. Nelfinavir was predicted to be a potential inhibitor of 2019-nCov main protease by an integrative approach combining homology modelling, molecular docking and binding free energy calculation. bioRxiv . 2020.

6. Mudhaliyar M, Gunapadam Mooligai vaguppu. 4th edition, Tamilnadu Siddha medical council: Chennai;1988.

7. Goswami D, Kumar M, Ghosh SK, Das A. Natural Product Compounds in Alpinia officinarum and Ginger are PotentSARS-CoV-2Papain like Protease Inhibitors. ChemRxiv, 2020.

8. Mishra AK, Singh BK, Pandey AK. Rev. Infect. Dis, 2010, 1: 134-139.

9. Prashant T. Phytochemical screening and Extraction. International Pharmaceutica Sciencia., 2001

10.Abbass MN, Rana FA, Chemical evaluation of weed seeds mixed with wheat grains at harvest. J anim plant sci. 2012, 22: 283-288.

11. Potterat O. Antioxidants and free radical scavengers of natural origin. Curr. Org. Chem. 2001,1: 415-440.

12. Chaurasia JK, Pandey N, Tripathi YB. Effect of hexane fraction of leaves of Cinnamomum tamala Linn on macrophage functions. Inflammopharmacology. 2010, 18: 147-154.

13. Saab AM, Gambari R, Sacchetti G, Guerrini A, Lampronti I, Tacchini M, El Samrani A, Medawar S, Makhlouf H, Tannoury M, Abboud J. Phytochemical and pharmacological properties of essential oils from Cedrus species. Natural Product Research. 2018, 32: 1415-1427.

14 Morris GM, Goodsell DS, Halliday RS, Huey R, Hart WE, Belew RK Olson AJ. Automated docking using a Lamarckian genetic algorithm and an empirical binding free energy function. J. Comput. Chem.1998,19: 1639-1662.

15.Solis FJ, Wets RJB. Minimization by random search techniques. Mathematics of operations research.1981, 6:19-30. 16 Chen W, Horby PW, Hayden FG, Gao GF. A novel coronavirus outbreak of global health concern. The Lancet, 2020, 395:470-473.

17. Manish, Studies on Computational Molecular Interaction between SARS-CoV-2 Main Protease and Natural Products .ChemRxiv,2020.

18. López-Lázaro M. Distribution and biological activities of the flavonoid luteolin. Mini reviews in medicinal chemistry, 2009, 9: 31-59.

19.Gescher K, Hensel A, Hafezi W, Derksen A, Kuhn J. Oligomeric proanthocyanidins from Rumex acetosa L. inhibit the attachment of herpes simplex virus type-1. Antiviral Res, 2011, 89: 9-18.

20.Roh C, Jo SK. (-)-Epigallocatechin gallate inhibits hepatitis C virus (HCV) viral protein NS5B. Talanta., 2011, 85: 26392642. 
Indo Global Journal of Pharmaceutical Sciences, 2020; 10(2): 19-25

21. Chen C, Qiu H, Gong J, Liu Q, Xiao H, Chen XW, Sun

BL, Yang RG. Epigallocatechin-3-gallate inhibits the replication cycle of hepatitis C virus. ArchVirol, 2012,157:1301-1312.

22. Thangadurai K, Rengasundari R, Vinayak S, Gayatri R, Suresh K, Banumathi V. In vitro free radical scavenging assay (DPPH (2, 2- diphenyl 1-2 picrylhydrazyl method) of Siddha HIV herbal formulation Deva Choornam. World Journal of Pharmaceutical Research, 2018, $7:$ 770-775.

23. Adem S, Eyupoglu V, Sarfraz I, Rasul A, Ali M. Identification of Potent COVID-19 Main Protease (Mpro) Inhibitors from Natural Polyphenols: An in Silico Strategy Unveils a Hope against CORONA. MDPI, Preprints 2020; 2020030333.

Indo Global Journal of Pharmaceutical Sciences( ISSN 2249 1023; CODEN- IGJPAI; NLM ID: 101610675) indexed and abstracted in CrossRef (DOI Enabling), UGC CARE Journal List, EMBASE (Elsevier), National Library of Medicine (NLM) Catalog (NCBI), ResearchGate, Publons (Clarivate Analytics), CAS (ACS), Index Copernicus, Google Scholar and many more. For further details, visit http://iglobaljournal.com 